\title{
APPLICATION OF COMPUTATIONAL METHODS FOR CREATING AND SELECTING POLYMERIC COMPOSITIONS WITH GIVEN PROPERTIES ${ }^{1}$
}

\author{
Evgenia Vyacheslavovna Derbisher \\ Candidate of Technical Sciences, Associate Professor, Department of Analytical, \\ Physical Chemistry and Physical Chemistry of Polymers, \\ Volgograd State Technical University \\ derbisher1@yandex.ru \\ Prosp. Lenina, 28, 400131 Volgograd, Russian Federation
}

\section{Vyacheslav Evgenievich Derbisher}

Doctor of Chemical Sciences, Professor, Department of High-Molecular and Fibrous Materials Technology, Volgograd State Technical University derbisher_ve@vstu.ru Prosp. Lenina, 28, 400131 Volgograd, Russian Federation

Abstract. The article discusses current mathematical methods (probabilistic, regression, correlation, fuzzy, graph, and others) used in the study of the structure and property dependencies of polymer compositions and polymer composite materials. The authors consider the methodology and theoretical aspects of modeling these dependencies, give technological calculations using models. The paper provides examples of the analysis of the particular case of complex chemical and chemical-technological systems, polymer compositions and composite (polymer) materials. The authors show a possible solution to the problems of assessing the quality of composite polymer materials and the rational choice of the composition in homogeneous sets using fuzzy sets.

Key words: chemical-technological systems, polymer composites, mathematical modeling, identification, fuzzy sets, optimization problem, choice of ingredients. 


\section{Introduction}

Products made of composite polymeric materials (CPM), especially structural, are widely used in various industries: construction, engineering, space and aviation technology, electronics, etc. The efficiency, reliability, durability, cost of products and demand for the technology market depend on many factors.

It should be noted that in addition to the widely used ones, dozens and hundreds of new CPMs are developed annually, which meet the new needs of technology. The most important technological and operational characteristics of CPM are studied, as a rule, by experimental methods, which requires sophisticated equipment and considerable time and material costs.

Promotion of the new CPM to the technological market is complicated by the fact that the physicomechanical and other properties of polymeric materials depend on many, often difficult to read, factors: first of all, the nature and properties of the polymer matrix, the properties of active and inactive filler, additives, functionality and quantity, parameters of preparatory and main technological operations, operating conditions of finished products. We emphasize that in the manufacture of parts from CPM, the provision of strength and other properties is not only related to the composition, but also depends largely on the control parameters of the technology.

Today, the creation of new CPMs and the assessment of the reliability of products from them requires, along with a preliminary experiment, a theoretical analysis of the deformation-strength and other performance characteristics, an assessment of the reliability of the structures with a further transition to theoretical tests, as well as the study of the possibility of using mathematical tools and methods for modeling CPM and shorten the path from design to technology. In this regard, the theoretical analysis of CPM by building mathematical models and identifying the properties of materials is relevant. In this article, the use of mathematical methods for identifying properties and designing CPM is considered in the general case by the example of chemical and chemical-technological systems (CTS) - specifically - to compositions of the form: "polymer - filler - additive". Theoretical analysis today has to be carried out for each position separately. We will give some explanations of what is meant by such an object of analysis as "composition". Even from the school course of chemistry, it is known that the mixture is a system spontaneously divided in the field of the earth, consisting of components, if you ensure their mobility. This mixture can then, in technological processes, produce an associated composition, losing the property of spontaneous separation and forming a single CTS. Here we will be interested in CPM with an indefinite set of ingredients, for which there is a high interest, both from the theoretical and applied science and technology.

It should be noted that the creation of CPM and their directed search with given performance characteristics is the modern goal of researchers and technologists working with CTS. There is no need to do without laws linking the structure of the material with its physicochemical properties. However, the nature of this connection is in most cases unclear and this forces researchers to delve deeper and deeper into establishing the "structure-property" relationship. Here, without setting problems for predicting the behavior of CPM as deformable multicomponent and multifactorial solids with a complex structure, the determination of effective chemical and physico-mechanical characteristics is one of the trends of the present time. Therefore, polymer materials science has shifted to a qualitatively new way of development - the use of highly intellectual, including mathematics and information technologies, in particular identification. 


\section{Research objective}

Identification of CPM properties today can be carried out at three sites: empirical, semi-empirical and non-empirical. The last two require mathematical modeling. Mathematical solution of problems of CPM identifying properties can consist of the following actions: formal presentation of the initial data, construction of mathematical models, research of models, creation of decision rules and recommendations, decision making. In private tasks that can be solved now it may look like this:

1) there is a set of polymer matrices, it is necessary to dwell on one;

2) there is a set of CPM of one direction of use; it is necessary to choose the optimal material using the restrictions;

3) there is a set of ingredients with the same functions; it is necessary to choose them so that CPM under the given conditions has optimal properties;

4) there are ingredients for different functional purposes; it is necessary to design a CPM with the intended physicochemical properties.

Using the example of a simple enumeration of functional additives in the composition of a CPM, we illustrate (Table 1) how voluminous the actual task of creating a CPM with given properties and what are the ways of their practical use is represented. Consider what basic mathematical and informational methods close to them can be used to solve these problems.

\section{Mathematical methods for predicting the properties of CPM}

The empirical mathematical models of CTS in the past time, as indeed now, relied on the physico-chemical characteristics of the substance and consisted in comparing the experimental data, according to the "impact-response" scheme, an understanding emerged that in chemistry for substances there is a relationship "composition (structure) - property", which can be expressed mathematically, in the form of a formula. We give historical examples. Baum in 1899 found that together with a decrease in solubility in olive oil from substance to substance, its narcotic power decreases [2], and Overton in 1901 found a similar dependence on the molar concentration of isocapillary-active solutions [19]. Later Hammet (1940) formulated the relationship of the quantitative relations of the structure and reactivity of some reagents involved in a chemical reaction [39]:

$$
\lg \frac{k}{k_{0}}=\sigma \rho
$$

where $k$ - the reaction rate constant in the side chain of meta- and para-substituted benzene derivatives; $k_{0}-$ unsubstituted compound rate constant; $\sigma-$ the substituent constant; $\rho-$ the reaction constant.

The ideas of Hammett received their certain development and on their basis a number of more complex equations were developed [19;25;38-40]. So, Taft in 1956, introduced the steric parameter and applied the Hammett equations to aliphatic systems [19]:

$$
\lg \frac{k}{k_{0}}=\sigma^{*} \rho+\delta E_{s}
$$


where $\sigma^{*}$ - the parameter is proportional to the contribution of inductive effect; $\delta_{I}, E_{s}-$ the steric parameter; $\delta$ - the correction factor.

Yukawa - Tsuno (1959) further expanded these ideas [19]:

$$
\begin{aligned}
& \lg \frac{k}{k_{0}}=\rho\left(\sigma+r\left(\sigma^{+}-\sigma\right)\right), \\
& \lg \frac{k}{k_{0}}=\rho\left(\sigma+r\left(\sigma^{-}-\sigma\right)\right),
\end{aligned}
$$

where $\sigma^{+}$- the parameter that takes into account the electron-donor resonance effect; $\sigma^{-}-$the parameter that takes into account the electron-acceptor resonance effect; $r-$ the correction factor.

Table 1

\begin{tabular}{|c|c|c|}
\hline Type of additive & Technical function & Active substance \\
\hline Anti-blocking & Sticking prevention & Silicic acid, amide waxes \\
\hline Antioxidant & $\begin{array}{l}\text { Thermo-Oxidation preven- } \\
\text { tion }\end{array}$ & Phenols, phosphides \\
\hline Flame retardant & Flammability reduction & $\begin{array}{l}\text { Inorganic oxides, metal } \begin{array}{l}\text { hydroxides, } \\
\text { halogen-containing, } \\
\text { containing, etc. }\end{array} \\
\text { phosphorus- }\end{array}$ \\
\hline Antislip & Roughening the surface & Ultrahigh molecular weight polyethylene \\
\hline Antistatic & Decrease in electrified & Alkylamines, metal powders \\
\hline Foaming & $\begin{array}{l}\text { Decrease in density, heat } \\
\text { conductivity }\end{array}$ & $\begin{array}{l}\text { Microcapsules with gases, derived from } \\
\text { carbonic acid }\end{array}$ \\
\hline Hydrophilic & Increased water wettability & Hydroxyl containing compounds \\
\hline Combined & $\begin{array}{l}\text { Light stabilizer antioxidant } \\
\text { and others (mainly for re- } \\
\text { cycling) }\end{array}$ & $\begin{array}{l}\text { Multinuclear phenols. Derivatives with } \\
-\mathrm{N}=\mathrm{N}-\text { bond }\end{array}$ \\
\hline Stretching modifier & $\begin{array}{l}\text { Additional elasticity, im- } \\
\text { pact resistance, resistance } \\
\text { to instantaneous overloads }\end{array}$ & $\begin{array}{l}\text { Brominated butyl rubber, clays, acrylic } \\
\text { copolymers, chloropolyethylene, etc. }\end{array}$ \\
\hline $\begin{array}{l}\text { Nucleates } \\
\text { (anti-fibrillation) }\end{array}$ & $\begin{array}{l}\text { Forming supramolecu- } \\
\text { lar structure, reducing } \\
\text { shrinkage }\end{array}$ & $\begin{array}{l}\text { Sodium benzoate, fluorescent organic } \\
\text { dyes }\end{array}$ \\
\hline Pigments and dyes & Giving color, stabilization & Polyvalent metal oxides, organic dyes \\
\hline Plasticizer & $\begin{array}{l}\text { Reduced intermolecular in- } \\
\text { teraction }\end{array}$ & $\begin{array}{l}\text { Esters of acids, organic phosphates, mod- } \\
\text { ified oils, derivatives of higher fatty acids }\end{array}$ \\
\hline $\begin{array}{l}\text { Processing (extru- } \\
\text { sion) }\end{array}$ & $\begin{array}{l}\text { Improved processability, re- } \\
\text { duced scoring }\end{array}$ & $\begin{array}{l}\text { Fluororganic, organosilicon derivatives, } \\
\text { metal stearates, derivatives of higher } \\
\text { fatty acids }\end{array}$ \\
\hline Light stabilizers & UV protection & $\begin{array}{l}\text { Benztriazole derivatives, benzophenone, } \\
\text { nickel and cobalt salts of phenols }\end{array}$ \\
\hline Sliding & $\begin{array}{l}\text { Reduced melt viscosity, im- } \\
\text { proved surface properties, } \\
\text { reduced friction coefficient }\end{array}$ & Higher Fatty Acid Derivatives \\
\hline
\end{tabular}

\section{Functional additives in the CPM}




\begin{tabular}{|l|l|l|}
\hline Type of additive & Technical function & Active substance \\
\hline Other functional & $\begin{array}{l}\text { Bioprotective, environ- } \\
\text { mental, pharmacological }\end{array}$ & Most diverse \\
\hline
\end{tabular}

Further, the idea of using mathematical relationships was aimed at estimating biological activity and in 1962 Hanch obtained a correlation equation [39] of the form:

$$
\lg \frac{1}{c}=4,08 \pi-2,14 \pi^{2}+2,78 \sigma+3,36
$$

where $c$ - the concentration causing a $10 \%$ increase in growth in the Abena test,

$$
\pi=\log \frac{P_{X}}{P_{H}}
$$

$P_{X}-$ the distribution coefficient of the substituted compound, $P_{H}-$ the distribution coefficient of the unsubstituted compound.

By the beginning of the seventies, the same Hench had published several more equations linking the biological activity and the physicochemical parameters of the substance:

$$
\lg \frac{1}{c}=3,24 \pi-1,97 \pi^{2}+1,86 \sigma+4,16,
$$

where $c$ - the concentration of a substance that causes a $10 \%$ growth of a plant in 24 hours.

$$
\lg \frac{1}{c}=0,256 \pi+2,42 \sigma 0,6,
$$

where $c$ - the concentration corresponding to the toxicity of $L D_{50}$.

Then he also applied a regression analysis, which allowed him to calculate the quantitative characteristics of the "structure - activity" links for a limited set of substances [25]:

$$
\lg \frac{1}{c}=0,88 \pi+0,74 \sigma+4,37,
$$

where the parameters are similar to the formula 6 .

This possibility led further to the very wide use of regression analysis, which was later influenced by the development of computer technology. It follows from the above that empirical statistical methods intended for the analysis of CTS based on regression analysis that were widely used were aimed at confirming the "structure-property" relationship in certain classes of CTS, including already in our time and in the CPM. However, they practically did not materialize in the constructive working tool of the technologist and now it is difficult to indicate whether specific technological implementations were achieved. To advance along this path, further developed structural analysis methods that made the transition from the characteristics of a substance to the characteristics of structural fragments, which already encoded individual fragments of chemical structures, and, quantitative characteristics of the substance were evaluated, and then identification was carried out [37]. Here has found 
some use and factor analysis [25]. So for the study of the properties exhibited by chemical compounds, the resulting productive formula was used:

$$
P_{i k}=\sum_{j=1}^{m} U_{i j} V_{j k},
$$

where $P_{i k}$ - the $k$-th property of the $i$-th compound; $U_{i j}$ - the $j$-th physico-chemical parameter of the $i$-th compound; $V_{j k}-j$-th physico-chemical or biological parameter of the $k$-th property.

Then came the numerical methods for solving problems. An example is the Runge Kutta method [30;32] for the numerical solution of differential equations describing relationships in a substance that require cumbersome calculations. The forecast was not reliable. Many other examples can be cited here; however, no real practical results have been achieved. At present, there has been a transition to a qualitatively new level of application of mathematical methods of analysis - analysis of complex systems, including CTS, and it has become possible to begin searching for ways to identify CPM properties.

We first note that with the "formulaic" approach, equations (1)-(9) remain to a certain extent valid only for a particular chemical system and their mechanical transfer to the CPM is problematic. Therefore, mathematical methods proved to be more promising: the above-mentioned regression analysis, mathematical statistics, cluster, factorial, discriminant, dispersive analyzes, pattern recognition, which were developed and disseminated in identifying the physical and mechanical properties of the CPM. Recall that CPM is a polymer matrix + filler + additives. Therefore, identification, within the framework of the tasks formulated above, can be carried out both for each component separately, and jointly and comprehensively. Consider in stages. First, simple semi-empirical mathematical models of the type (1)-(8) appeared, connecting one independent parameter and one dependent, for example, the amount of filler in a polymer matrix and the strain modulus $E_{c}$. Let us give the classical Einstein equation [4]:

$$
E_{c}=E_{m}(1+2,5 v) .
$$

where $E_{m}$ - the deformation modulus of the polymer matrix; $v$ - the volumetric content of the dispersed filler.

A more complicated expression of Guta - Smallwood [18] has the form:

$$
E_{c}=E_{m}\left(1+2,5 v+14,1 v^{2}\right) .
$$

However, in areas where $v>0,3$, the values $E_{c}$ calculated using these formula (10)(11) begin to differ significantly from the experimental data. Therefore, mathematical models began to complicate:

- the equation of the upper limit of the strain modulus:

$$
E_{c}=E_{m}(1-v)+v E_{f} .
$$

- Eilers equation - Van Dijk [31]:

$$
E_{c}=E_{m}\left[1+\frac{1,25 v}{1-\frac{v}{0,74}}\right]^{2}
$$


- Keiner equation [10]:

$$
E_{c}=E_{m} \frac{E_{f} A_{k}+B_{k}}{E_{m} A_{k}+B_{k}}
$$

Where

$$
A_{k}=\frac{v}{(7-5 \mu) E_{m}+(8-10 \mu) E_{f}} ; \quad B_{k}=\frac{1-v}{15(1-\mu)} ;
$$

$\mu-$ Poisson's ratio (for construction materials $\mu \approx 0,5$ ).

Almost no progress was made further in this part, and the empirical approaches remain the most frequent within the framework of the theory-practice approach. You can selectively note the recent work $[5 ; 6 ; 27 ; 33]$. Achievements in this area are still most relevant to the polymer matrix. They allow the use of semi-empirical calculation methods $[22 ; 23]$ for the analysis of possible physicomechanical characteristics using the additivity feature. The initial basis is the chemical formula of a separate polymer unit: in the simplest case for polyethylene, this is $-\mathrm{CH}_{2}-\mathrm{CH}_{2}-$. Here the additivity consists in the fact that a significant number of characteristics of a substance calculated per mole can be approximately calculated by summing the contributions of atoms of groups or bonds by the simple relation:

$$
F=\sum n_{i} F_{i}
$$

where $F$ - the molar characteristic, and $n_{i}$ - the number of components of type $i$ contributing to this characteristic, formula (15) is similar to formula (9).

High-molecular compounds are a good object for using the additivity principle due to the fact that the structure of most of them of practical importance is formed by sequences of fairly simple groups. Usually such reference data as the molar mass $(M)$, the molar volume $(V)$, the molar heat capacity $\left(C_{p}\right)$, the molar enthalpy of melting $\left(D H_{m}\right)$, the molar cohesion energy $\left(E_{c o h}\right)$, the molar glass transition parameter $(Y g)$, the molar parameter melting $\left(Y_{m}\right)$, molar refraction $(R)$, molar dielectric polarization $(P)$, molar magnetic susceptibility $(C)$, molar parameter of the speed of sound in the polymer $(U)$ and some others. This principle of additivity for high-molecular compounds was originally developed by A.A. Askadsky [1], and then he received wide distribution in theory and practice. Using the numerical values of the physicochemical properties of the data for individual groups of the link, it is possible to approximately calculate the total value of the calculated parameter for the entire macromolecule - these are transition temperatures, cohesion characteristics, thermal properties, calorimetric characteristics, properties of polymers in force fields, electrical and thermal properties, and individual rheological options. A lot of research is devoted to the state that an individual macromolecule is capable of taking and the configuration of the entire molecular ensemble. The properties observed in practice are the result of averaging over many different polymer states. Estimate the rms dimensions of the polymer coil, rms dipole moment and polarization, characteristics of light scattering, etc. This approach begins to give serious deviations in the calculation of the characteristics of complex polymer structures, especially with heteroatoms, cycles, linear crosslinks and spatial structures. Nevertheless, calculations with the use of additivity in practice are used to such an extent that they are included in the calculation tasks for students of higher educational institutions $[7 ; 20]$. For academic and individual technological purposes, there is a set of calculation methods for determining the thermodynamic characteristics of macromolecules depending on temperature [41]. Among others in this part, we note the coefficient of thermal expansion, the parameters of phase equilibria, etc. Identification of the properties of the polymer matrix in 
the composition of the CPM today is also performed by the methods of molecular dynamics or Monte Carlo to establish the values of characteristics depending on the specified parameters of the macromolecule [29]. We give a small calculation example. The task is as follows. To estimate the glass transition temperature (TD) of polyethylene terephthalate according to the chemical formulas of the structural unit [7]:

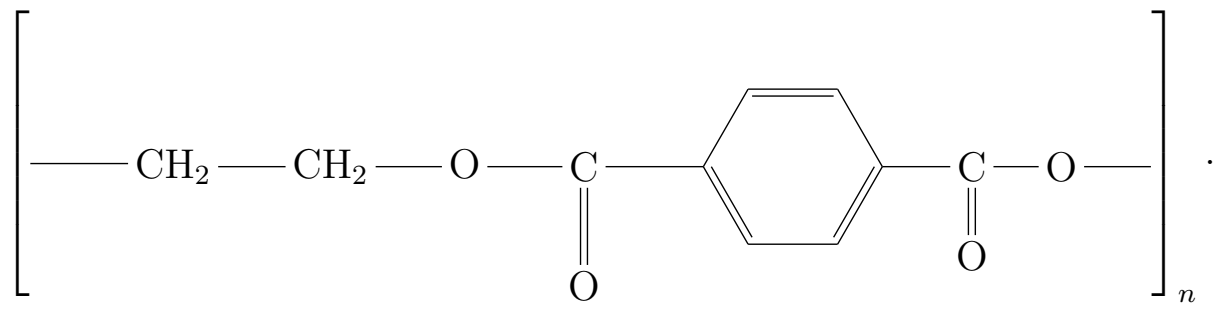

We have the values of group contributions $Z_{i}$ and $Y g_{i}$ :

$$
2\left(-\mathrm{CH}_{2}-\right) \quad Z_{i}=2 ; Y g_{i}=340
$$
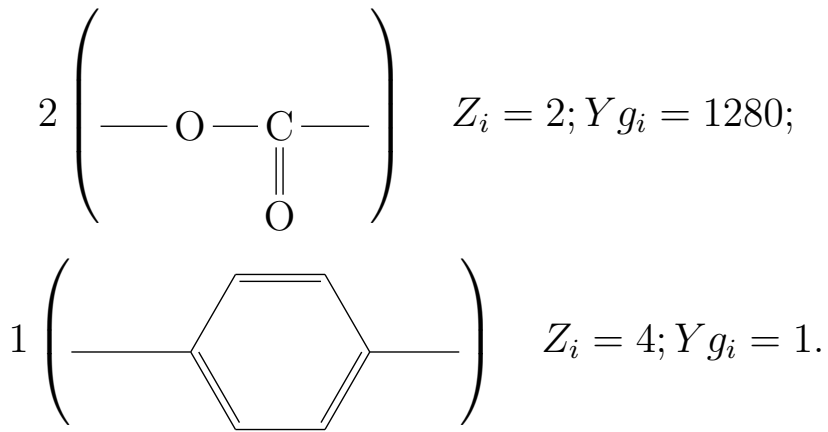

By the principle of additivity we get:

$$
\begin{gathered}
Z_{i}=2+4+4=10 \\
Y g_{i}=340+1280+1850=3470,
\end{gathered}
$$

the calculated value of TD will be equal to:

$$
T_{d}=\frac{Y g}{Z}=\frac{3470}{10}=347(K) .
$$

The real glass transition temperature of this polymer is $343-353 \mathrm{~K}$. Thus, it is possible to calculate the approximate value of many parameters of various polymers and copolymers (polymer matrices) and software products have been created for this purpose [36]. Here we are talking about information technology. For new objects it requires a serious experimental verification.

As for the CPM itself, taking into account, as mentioned above, their heterogeneity and multi-factorialness, it can be said that direct arithmetic calculations are most associated with material balance, and mathematical models have a "quasi-predictive" character [26]. Here is an illustration. In $[42 ; 43]$, the identification of CPM properties is considered when constructing and training an artificial neural network. An attempt has been made to evaluate various parameters and indicators. To ensure the selection of optimal additives (softeners) in the composition of the CPM, which would provide the specified physical and mechanical 
properties, a statistical analysis of the initial data - recipes for mixtures of compositions based on SKS-30 APC rubber was made. The construction is based on a regression analysis. Here identification is nothing more than a "prescription" character. Other studies of this profile also deal with the optimal choice of ingredients [34].

It should be noted that the regression analysis, which is highly developed in this part, makes it possible to solve particular problems when studying CPM: identifying the composition for each element of the CPM, identifying the temperature and power range of testing and operation, and identifying environmental factors. For example, it was used to establish a simple relationship between CPM factors in the form of an Lagrange interpolation polynomial of degree $n-1$. On the basis of experimental data, a relationship was established between the concentration of the crosslinking agent in the composition and the degree of crosslinking of components in the film of this composite [28]:

$$
y=6,09+0,05587 x-0,1924 x^{2}-0,01129 x^{3}-0,000172 x^{4},
$$

$y$ - the degree of crosslinking; $x$ - the concentration of the crosslinking agent.

In this part of the study, the activity is obvious. For CPM, there are in addition to static, such as in the specified example (16), the concentration of the crosslinking agent, an extensive group of dynamic, that is, time-dependent characteristics, such as diffusion, viscosity, sedimentation coefficients, thermal conductivity, response to external influences, rheology, etc. for predictions of values based on molecular parameters today use a numerical dynamic type experiment (including methods of non-equilibrium molecular dynamics) $[35 ; 41]$. Here, progress has been made in the analysis of ordered microstructures in polymer matrices of block and statistical nature, having different monomer units, in which specific interactions (including electrostatic) manifest themselves.

This task is interesting both for understanding the features of self-organization of macromolecules, and for applied aspects of the controlled formation of a structure when creating a CPM. Another particular in this series is the problem of selecting the CPM ingredient (with a known polymer matrix) according to the boundary conditions. In this part of the achievements are most associated with the use of fuzzy sets (FS) and fuzzy mathematical approaches.

Here, the solution of the problem of selecting additives for a CPM with a known polymer matrix and a given function of fillers and additives is considered in most detail. When forming the task, it was found that the initial information is vague and contradictory, and exact mathematical methods are hardly applicable [13]. The following tasks were solved using FS in this area $[9 ; 14]$.

1) Ranking active supplements.

2) Classification of active additives.

3) Verification of the initial information.

4) Examination of known ingredients.

5) Identification of the properties of new ingredients.

6) Construction of virtual additives.

\section{The ranking of active additives}

The task of ranking active additives to the CPM, considered in $[8 ; 11]$, was to arrange them in order of increasing efficiency. The task is general and formalized as follows. 
The set $S=\left\{s_{i} \mid i=\overline{i, n}\right\}$, consisting of $n$ objects (additives). For each object $s_{i}, m$ characteristics $Q_{i j}, j=\overline{i, m}$ are determined. The reference object $s_{0}$ and its characteristics $Q_{0 j}$ are distinguished, with $s_{0}$ being either an element of the set $S$ or not. The characteristics of $Q_{0 j}$ are chosen in such a way that $s_{0}$ is optimal.

Finally, the task in its most general form is formulated as follows: it is required to rank the elements of the set $S$ according to the given $m$ characteristics $Q_{i j}$ for compliance with the standard $s_{0}, i=\overline{i, n}, j=\overline{i, m}$.

The solution is that for each characteristic $Q_{i j}$ a fuzzy set is constructed

$$
\hat{Q}_{i j}=\left\{x_{j} \mid \mu_{i j}\left(x_{j}\right)\right\}, \quad \mu_{i j}\left(x_{j}\right)=e^{-\frac{\ln 2}{\delta_{i j}^{2}}\left(x_{j}-q_{i j}\right)^{2}},
$$

where $x_{j} \in \mathbb{R}, i=\overline{i, n}, j=\overline{i, m}$. A certain membership function is involved in the calculation.

To determine the extent to which the characteristic $Q_{i j}$ of the object $s_{i}$ is close to the characteristic $Q_{0 j}$ of the reference object $s_{0}$, the equality index $v_{i j}$ of the corresponding fuzzy sets is calculated [12]:

$$
v_{i j}=\max _{R} \min \left(\mu_{i j}\left(x_{j}\right), \mu_{0 j}\left(x_{j}\right)\right)
$$

After a weighted vote we get the integral assessment $v_{i}$ of the correspondence of the set of characteristics of the object $s_{i}$ to the set of characteristics of the object $s_{0}$ :

$$
v_{i}=\sum_{j=1}^{m} \alpha_{j} v_{i j}
$$

where $\alpha_{j} \geq 0, \sum_{j=1}^{m} \alpha_{j}=1$. Here $\alpha_{j}$ is the weight of the $j$-th criterion and shows the level of its importance.

The result is $v_{i}$, indicating the level of compliance of the compound $s_{i}$ with the requirements for the active additive. A practical example of the results of calculations according to the above scheme is shown in Table 2 .

Data on polyethylene (PE) light stabilizers

\begin{tabular}{|c|c|l|l|l|}
\hline$i$ & Structural formula, $s_{i}$ & \multicolumn{2}{|c|}{ Specifications } & Efficiency, $v_{i}$ \\
\cline { 1 - 4 } & $\begin{array}{l}\text { Melting } \\
\text { temperature } \\
Q_{i 1},{ }^{\circ} \mathrm{C}\end{array}$ & $\begin{array}{l}\text { Concentration } \\
\text { in PE } Q_{i 2}, \%\end{array}$ & \\
\hline 0 & 218 & $0,01-0,2$ & 1,00 \\
\hline
\end{tabular}




\begin{tabular}{|l|l|l|l|l|}
\hline$i$ & \multicolumn{2}{|c|}{ Specifications } & \multirow{2}{*}{ Efficiency, $v_{i}$} \\
\cline { 2 - 5 } & $\begin{array}{l}\text { Melting } \\
\text { temperature } \\
Q_{i 1},{ }^{\circ} \mathrm{C}\end{array}$ & $\begin{array}{l}\text { Concentration } \\
\text { in PE } Q_{i 2}, \%\end{array}$ & \\
\hline 1 & 147 & $0,2-5$ & 0,63 \\
\hline 3
\end{tabular}

\section{Classification of additives}

The above approach has also been applied for classification [9], which is carried out according to the degree of impact of the additive on the final CPM product. For this, classes of additives are distinguished: highly active, moderately active, little active, inactive, etc., which are interpreted as follows:

1) Highly active - additives that produce a pronounced effect on the final CPM.

2) Moderately active - additives produce some effect, but this requires a high concentration, other additives or any other additional conditions.

3) Little active - the effect is practically not observed, at least, additives of this class do not impair the performance of the final CPM.

4) Inactive - the effect either does not manifest itself in any way, or the indicators of CPM deteriorate.

The results of the classification of a sample of light stabilizers for the CPM from Table 2 are given in Table 3. 


\section{Verification of the initial information}

When selecting and sorting information for predicting CPM, there are several problems [9].

- in different sources the values of the same indicator differ for both the polymer matrix and the ingredients. After ranking, the ingredients take their place among the activities, while comparing its data with the data of neighboring ones, conclusions can be drawn about the objectivity of the information;

- subjective and inconsistent opinions, such as, for example: "good stabilizer" - that in one case is considered as "good", in the other is rated as "satisfactory". Thus, "good" in one information source is often not equal to "good" in another. For each of them, you can rank the ingredients separately, coordinate the information, compare the indicators and limit the area of the computational experiment. From the foregoing it is clear that the verification principle itself is not complicated, but it requires a lot of "paper" work. The tested ingredients are ranked together with the already proven ones and, based on the places they occupy, certain conclusions are drawn about the boundary conditions.

\section{Examination of organic compounds}

In [40], related to a CPM study, an examination is the conclusion about how well an ingredient (additive) satisfies the set conditions in a CPM composition.

So, some additive $s_{0}$ fully satisfies all requirements (for example, in Table 2 this compound 0 ). Then, in order to examine the compound $s$, the level $v$ is calculated for $s$ with respect to the standard $s_{0}$, as shown above. Level $v$ will show how $s$ satisfies the requirements.

Table 3

Classification of polyethylene light stabilizers

\begin{tabular}{|c|c|lc|}
\hline $\begin{array}{l}\text { No addi- } \\
\text { tives, } i\end{array}$ & \multicolumn{2}{|l|}{ Classification(value $v$ ) } \\
\hline 1 & $\begin{array}{l}\text { Moderately } \\
(0,60-0,69)\end{array}$ & active \\
\hline 2 & & $\begin{array}{l}\text { Moderately } \\
(0,60-0,69)\end{array}$ & active \\
\hline 3 & & $\begin{array}{l}\text { Moderately } \\
(0,60-0,69)\end{array}$ & active \\
\hline
\end{tabular}




\begin{tabular}{|c|c|c|}
\hline $\begin{array}{l}\text { No addi- } \\
\text { tives, } i\end{array}$ & Formula & Classification(value $v$ ) \\
\hline 4 & & $\begin{array}{l}\text { Highly active }(0,70- \\
1,00)\end{array}$ \\
\hline 5 & & $\begin{array}{l}\text { Highly active }(0,70- \\
1,00)\end{array}$ \\
\hline
\end{tabular}

For example, for PE light stabilizers the best (in terms of technology) are additives No. 4 and 5 (Table 3). Identification of active additive properties.

The problem is that if there are several classes of additives and a new chemical compound is presented, then it is necessary to identify the class to which it belongs.

The identification method proposed in [11] is based on the fact that adding an element that already belongs to this set will not change the set. To do this, a set of descriptors is built, for example, by combining the sets of descriptors of each additive, a set of descriptors of the class of additives is created, that is, a statistical image of the additive to the CPM is built. Further, to identify the relevant properties of a substance, descriptors of this chemical compound are added to the statistical image, and if the compound is an active additive, then the new image should differ little from the previous one, and, on the contrary, the differences will be significant if the compound is not.

The computational steps here are that, based on the relative frequencies of occurrence of structural descriptors, FS descriptors should be built for each class of additives. And to assess the changes that have occurred in NM after the addition of a new additive, it is proposed to use the FS dissimilarity index [24].

\section{Construction of virtual additives based on the forecast}

The method for constructing active additives to a CPM described in [16;17] is based on a limited search of real and virtual chemical structures of organic compounds with regard to their descriptors, and the identification method mentioned above is used to evaluate the activity of a specific compound as a functional additive to the CPM. To search, you can analyze, virtual organic compounds all in a row. However, the array of such so large that this procedure would be delayed indefinitely. In addition, the vast majority of compounds would be idled. Therefore, a limited search should be carried out, with boundary conditions that can be accomplished using the statistical image mentioned above. Here, only those descriptors that describe the structural fragments of a chemical compound formula are taken into consideration. By choosing those of which the frequency of occurrence is greatest, virtual connections are being constructed that are candidates for identification, synthesis, and testing.

\section{Conclusion}

In solving the problem of identifying the CPM, certain changes have been noted. At the same time, within the framework of identification based on mathematical methods, 4 stages 
were outlined: Formalized description and design of a set of features;

- development of models of identification of technological activity;

- establishing the influence of CPM ingredients on the physicomechanical properties;

- design of new CPM.

Figure 1 shows the systematization of methods for the analysis of CTS, including CPM, including those considered in the article that need to be used and developed.

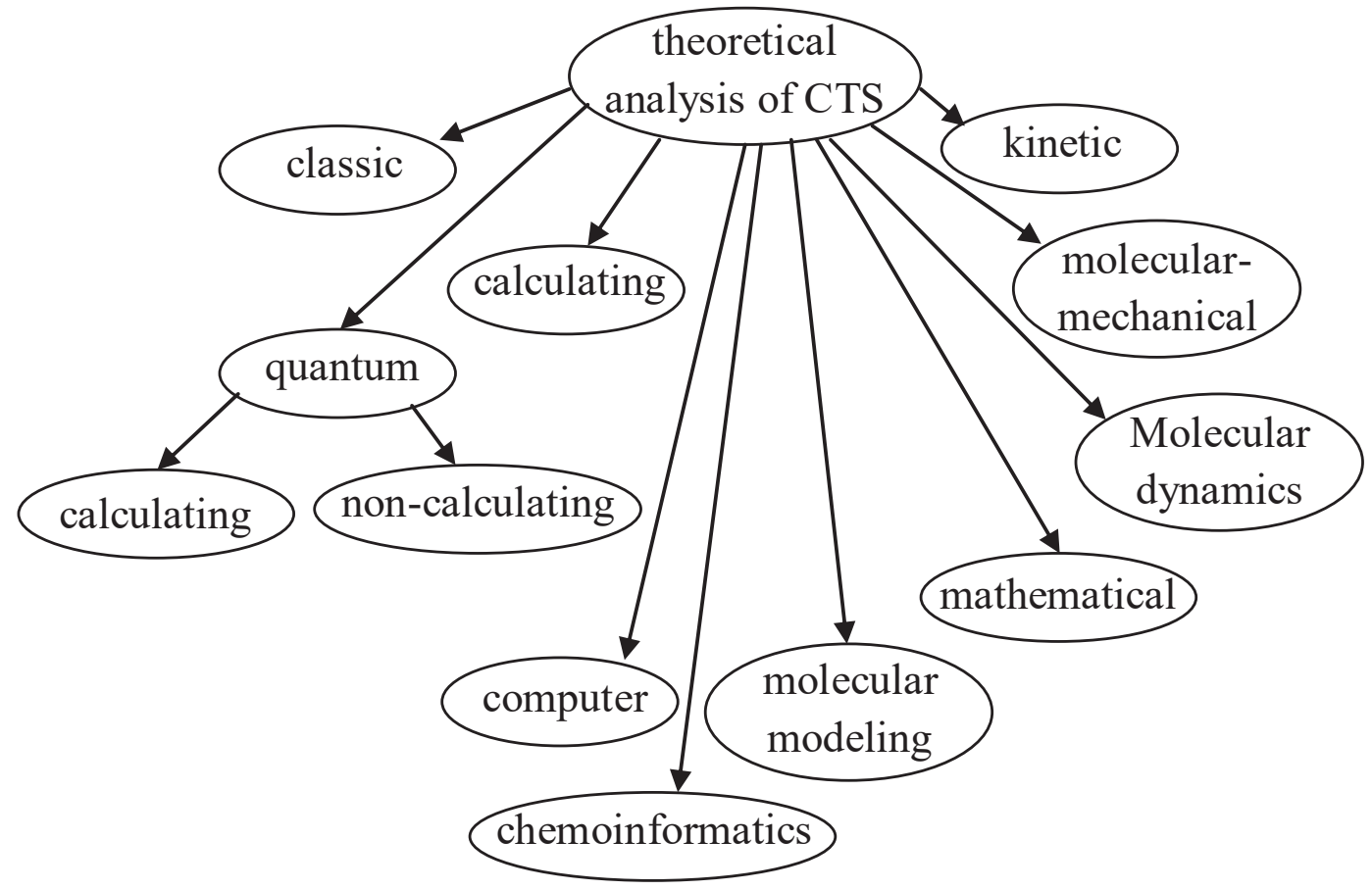

Fig. 1. Areas and methods of forecasting CTS

In general, their further development is associated with the expansion of mathematical approaches and the increasing involvement of information technologies and the development of subject representations in the field of quantitative relations "structure-property" of the CPM. The possibilities of using these technologies for world practice in the analysis of CTS are shown in Fig. 2 and most likely the space is even wider.

And most likely, on this basis, in the coming years, it will be possible to predict an indefinite, constantly expanding set of physico-chemical and performance properties of a CPM and the creation of new technological products.

In this direction there are already advances. For example, the only fundamental publication in its genre in world practice [21] which contains the chapter "Principles of regulation of CPM properties" and also summarizes data on individual issues of modeling the "structure property" dependence in this area. 


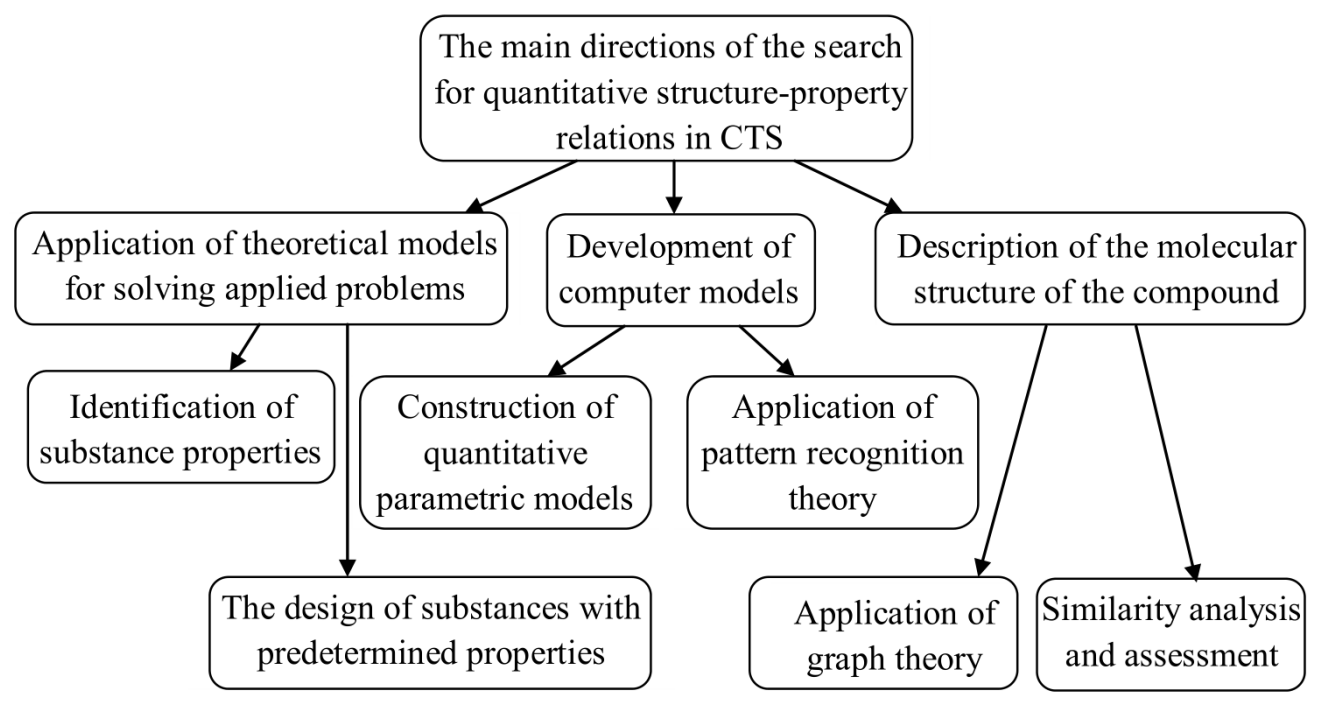

Fig. 2. The main directions of the study of the dependence of "structure-property "CTS"

\section{REMARK}

${ }^{1}$ The reported research was funded by Russian Foundation for Basic Research and the government of Volgograd region, grant № 18-48-340011.

\section{REFERENCES}

1. Askadskiy A.A., Kondrashchenko V.I. Kompyuternoe materialovedenie polimerov. Atomno-molekulyarnyy uroven [Computer Materials Polymers. Atomic and Molecular Level]. Moscow, Nauchnyy mir Publ., 1999. 543 p.

2. Barlow R. Vvedenie v khimicheskuyu farmakologiyu [Introduction to Chemical Pharmacology]. Moscow, Izdatelstvo inostrannoy literatury Publ., 1959. 464 p.

3. Belokurova A.P., Burmistrov V.A., Ageeva T.A. Termomekhanicheskiy metod issledovaniya polimerov: metodicheskie ukazaniya $k$ laboratornomu praktikumu po khimii $i$ fizike polimerov [Thermomechanical Method for the Study of Polymers: Guidelines for Laboratory Practice in Chemistry and Physics of Polymers]. Ivanovo, Ivanovo State University of Chemical Technology, 2006. 36 p.

4. Besse A.L. Mnogoobraziya Eynshteyna [Einstein's Manifolds]. Moscow, Mir Publ., 1990. 384 p.

5. Bobryshev A.N., Erofeev V.T., Kozomazov V.N. Polimernye kompozitsionnye materialy [Polymeric Composite Materials]. Moscow, Izdatelstvo ASV Publ., 2013. 480 p.

6. Bondarev A.B. Prognozirovanie tsiklicheskoy dolgovechnosti polimernykh kompozitsionnykh materialov: dis. ... kand. tekhn. nauk [Prediction of Cyclic Durability of Polymer Composite Materials. PhD Dissertation]. Lipetsk, 2011. 180 p.

7. Borisevich S.S., Yanborisov V.M. Raschet fiziko-khimicheskikh svoystv polimernykh materialov [Calculation of Physico-Chemical Properties of Polymeric Materials]. Ufa, UGES Publ., 2011. 31 p.

8. Derbisher V.E., Germashev I.V., Bodrova G.G. Kolichestvennaya otsenka effektivnosti termo- i fotostabiliziruyushchikh dobavok v polimernykh kompozitakh na osnove predstavleniy o nechetkikh mnozhestvakh [Quantitative Assessment of the Effectiveness of Thermal and 
Photostabilizing Additives in Polymer Composites Based on Ideas About Fuzzy Sets]. Vysokomolekulyarnye soedineniya, 1997, vol. 39, no. 6, pp. 960-964.

9. Derbisher E.V., Germashev I.V., Derbisher V.E. Analiz svoystv ingredientov polimernykh kompozitsiy s ispolzovaniem nechetkikh mnozhestv [Analysis of the Properties of Ingredients of Polymer Compositions Using Fuzzy Sets]. Izvestiya VolgGTU. Ser. Aktualnye problemy upravleniya, vychislitelnoy tekhniki $i$ informatiki v tekhnicheskikh sistemakh [Izvestiya VolgGTU. Ser. Actual Problems of Management, Computing and Computer Science in Technical Systems: Interuniversity Collection of Scientific Articles], 2007, vol. 2, no. 2, pp. 28-31.

10. Dol A.V., Ivanov D.V. Vvedenie v teoriyu uprugosti [Introduction to the Theory of Elasticity]. Saratov, Amirit Publ., 2016. 28 p.

11. Germashev I.V., Vasilyeva V.D., Derbisher V.E., Derbisher E.V., Silina A.Yu. Primenenie teorii nechyotkikh mnozhestv dlya resheniya zadach khimicheskoy tekhnologii [Application of the Theory of Fuzzy Sets for Solving Problems of Chemical Technology]. Informatsionnye tekhnologii [Information Technologies], 2009, vol. 15, no. 5, pp. $72-79$.

12. Germashev I.V., Derbisher V.E. Svoystva unimodalnykh funktsiy prinadlezhnosti v operatsiyakh s nechetkimi mnozhestvami [Properties of Unimodal Membership Functions in Operations with Fuzzy Sets]. Izvestiya vuzov. Matematika [Russian Mathematics], 2007, vol. 51, no. 3, pp. 77-80.

13. Germashev I.V., Derbisher V.E., Derbisher E.V., Markushevskaya E.A. Analiz nechetkikh dannykh dlya optimizatsii khimiko-tekhnologicheskikh sistem [Analysis of Fuzzy Data for the Optimization of Chemical-Technological Systems]. Informatsionnye tekhnologii [Information Technologies], 2018, vol. 24, no. 3, pp. 153-160.

14. Germashev I.V., Derbisher V.E., Orlova S.A. Otsenka aktivnosti antipirenov v elastomernykh kompozitsiyakh s pomoshchyu nechetkikh mnozhestv [Evaluation of Activity of Flame Retardants in Elastomeric Compositions Using Fuzzy Sets]. Kauchuk i rezina, 2001, no. 6 , pp. $15-17$.

15. Germashev I.V., Derbisher E.V., Derbisher V.E. Prinyatie resheniy o vybore ingredientov polimernykh kompozitsiy v usloviyakh nechyotkoy informatsii [Making Decisions on the Choice of Ingredients of Polymer Compositions in Conditions of Fuzzy Information]. Plasticheskie massy [Plastics], 2007, no. 7, pp. 24-27.

16. Germashev I.V., Derbisher V.E., Zotov Yu.L., Tsapleva M.N., Konnova E.V., Vasilyev P.M. Kompyuternoe konstruirovanie aktivnykh dobavok dlya polivinilkhlorida [Computer Design of Active Additives for Polyvinyl Chloride]. Plasticheskie massy [Plastics], 2001, no. 7 , pp. 36-38.

17. Germashev I.V., Derbisher V.E., Tsapleva M.N., Derbisher E.V. Kompyuternoe konstruirovanie khimicheskikh soedineniy s zadannymi svoystvami [Computer Design of Chemical Compounds with Desired Properties]. Teoreticheskie osnovy khimicheskoy tekhnologii [Theoretical Foundations of Chemical Technology], 2004, vol. 38, no. 1, pp. 90-95.

18. Goldman A.Ya. Prognozirovanie deformatsionno-prochnostnykh svoystv polimernykh $i$ kompozitsionnykh materialov [Prediction of Deformation and Strength Properties of Polymeric and Composite Materials]. Leningrad, Khimiya: Leningradskoe otdelenie Publ., 1988. $271 \mathrm{p}$.

19. Johnson K. Uravnenie Gammeta [Hammett Equation]. Moscow, Mir Publ., 1977. $240 \mathrm{p}$

20. Kablov V.F, Sinkov A.V. Additionye tekhnologii v proizvodstve polimernykh izdeliy [Additive Technologies in the Production of Polymer Products]. Volzhsky, VPI (filial VolgGTU) Publ., 2018. 21 p.

21. Kerber M.L. Polimernye kompozitsionnye materialy. Struktura. Svoystva. Tekhnologiya [Polymeric Composite Materials. Structure. Properties. Technology]. SPb, TsOP «Professiya» Publ., 2014. 560 p.

22. Kryzhanovskiy V.K., Burlov V.V. Prikladnaya fizika polimernykh materialov [Applied Physics of Polymeric Materials]. SPb, SPbGTI Publ., 2001. 261 p. 
23. Kuleznev V.N., Shershnev V.A. Khimiya i fizika polimerov [Chemistry and Physics of Polymers]. Moscow, Vysshaya shkola Publ., 1988. 312 p.

24. Nechetkie mnozhestva i teoriya vozmozhnostey. Poslednie dostizheniya [Fuzzy Sets and the Theory of Possibilities. Recent Achievements]. Moscow, Radio i svyaz Publ., 1986. $408 \mathrm{p}$.

25. Nizhniy S.V., Epstein N.A. Kolichestvennye sootnosheniya «khimicheskaya struktura biologicheskaya aktivnost» [Quantitative "Chemical Structure - Biological Activity" Relations]. Uspekhi khimii [Russian Chemical Reviews], 1978, vol. 47, no. 4, pp. 739-772. DOI: https://doi.org/10.1070/RC1978v047n04ABEH002225.

26. Norkin V.S., Tikhomirov S.G. Prognozirovanie svoystv polimernykh kompozitsiy na baze metodov iskusstvennogo intellekta [Prediction of Properties of Polymer Compositions Based on Artificial Intelligence Methods]. Nauka, obrazovanie, obshchestvo: tendentsii $i$ perspektivy razvitiya: materialy $V$ Mezhdunarodnoy nauchno-prakticheskoy konferentsii. (Cheboksary, 27 maya 2017g.) [Science, Education, Society: Trends and Development Prospects: Materials of the V International Scientific Practical Conference. (Cheboksary, May 27, 2017)] Cheboksary, TsNS «Interaktiv plyus» Publ., 2017, vol. 1, no. 6, pp. $26-230$.

27. Omran K. Prognozirovanie vibratsionnoy bezopasnosti avtomobilya s vtorichnoy sistemoy podressorivaniya kuzova iz polimernykh kompozitsionnykh materialov: avtoreferat dis. ... kand. tekh. nauk [Prediction of the Vibration Safety of a Car with the Secondary Suspension System of the Body Made of Polymer Composite Materials. PhD Dissertation]. Moscow, 2007. 16 p.

28. Pasechnik M.V., Kucher E.A. Matematicheskoe modelirovanie protsessov sshivki sostavlyayushchikh polimernoy kompozitsii [Mathematical Modeling of the Processes of Cross-Linking the Components of the Polymer Composition]. Vostochno-Evropeyskiy zhurnal peredovykh tekhnologiy [East European Journal of Advanced Technologies], 2016, vol. 2, no. 6, pp. 4-12.

29. Pen V.R., Levchenko S.I. Modelirovanie metodom Monte-Karlo destruktsii makromolekul so slozhnoy topologicheskoy strukturoy [Monte Carlo Simulation of the Destruction of Macromolecules with a Complex Topological Structure]. Modern high technologies, 2008, no. 6, pp. 45-46.

30. Rodionov A.A., Olshevskiy M.V. Matematicheskoe modelirovanie fiziko-khimicheskikh protsessov v atmosfere goroda [Mathematical Modeling of Physicochemical Processes in the Atmosphere of a City]. Shkola molodykh uchenykh pri 10-oy mezhdunarodnoy konferentsii Matematicheskie metody v khimii i khimicheskoy tekhnologii: Tez. dokl. [School of Young Scientists at the 10th International Conference Mathematical Methods in Chemistry and Chemical Technology] Tula, Goskomvuz RF Publ., 1996, pp. 195-196.

31. Rozenblit A.B., Golender V.E. Logiko-kombinatornye metody v konstruirovanii lekarstv [Logical and Combinatorial Methods in Drug Design]. Riga, Zinatne Publ., 1983. $352 \mathrm{p}$.

32. Samarskiy A.A., Gulin A.V. Chislennye metody [Numerical Methods]. Moscow, Nauka Publ., 1989. 432 p.

33. Solovev V.N. Prognozirovanie radiatsionnogo stareniya polimernykh materialov: dis. ... dokt. tekh. nauk [Prediction of Radiation Aging of Polymeric Materials. Doctor Dissertation]. Moscow, 2001. 248 p.

34. Startsev O.V., Anikhovskaya L.I., Litvinov A.A., Krotov A.S. Povyshenie dostovernosti prognozirovaniya svoystv polimernykh kompozitsionnykh materialov pri termovlazhnostnom starenii [Increasing the Reliability of Predicting the Properties of Polymer Composites in Hygrothermal Aging]. Doklady Akademii nauk. Khimicheskaya tekhnologiya [Doklady Chemistry], 2009, vol. 428, no. 1, pp. 56-60.

35. Shirvanyants D.G., Khalatur P.G. Kompyuternoe modelirovanie polimerov [Computer Modeling of Polymers]. Tver, Tverskoy gosudarstvennyy universitet Publ., 2000. $156 \mathrm{p}$.

36. Askadskii A.A. Computational Materials Science of Polymers. Cambridge, Cambridge International Science Publishing, 2001. 650 p. 
37. Goodford P.G. Prediction of Pharmacological Activity by the Method of Physicochemical - Activity Relationships. Advances in Pharmacology and Chemotherapy, 1973, vol. 11, pp. 51-97.

38. Hansch C., Fujita T. $\rho-\sigma-\pi$ Analysis. A Method for the Correlation of Biological Activity and Chemical Structure. Journal of American Chemical Society, 1964, vol. 86, no. 8, pp. 1616-1626.

39. Hansch C., Maloney P.P., Fujita T. Correlation of Biological Activity of Phenoxyacetic Acids with Hammett Substituent Constants and Partition Coefficients. Nature, 1962, vol. 194, no. 4824 , pp. $178-179$.

40. Hansch C., Muir R.M., Fujita T., Maloney P.P., Geiger F., Streich M. The Correlation of Biological Activity of Plant Growth Regulators and Chloromycetin Derivatives with Hammett Constants and Partition Coefficients. Journal of American Chemical Society, 1963, vol. 85, no. 20, pp. 2817-2824.

41. Khalatur P.G. Computer Simulations of Polymer Systems. New York, Gordon and Breach Publ., 1996. 487 p.

42. Navratil M., Kolomaznik K., Kresalek V. Approach to Mathematical Model of the Cross-linking Reaction of Polymer Composite. AT\&P journal PLUS2, 2007, vol. 1, pp. 2123.

43. Wulkow M. Computer Aided Modeling of Polymer Reaction Engineering. Macromolecular Reaction Engineering, 2008, vol. 2, iss. 6, pp. 461-494.

\section{ПРИМЕНЕНИЕ ВЫЧИСЛИТЕЛЬНЫХ МЕТОДОВ ДЛЯ СОЗДАНИЯ И ВЫБОРА ПОЛИМЕРНЫХ КОМПОЗИЦИЙ С ЗАДАННЫМИ СВОЙСТВАМИ}

\section{Евгения Вячеславовна Дербишер}

Кандидат технических наук, доцент кафедры аналитической, физической химии и физико-химии полимеров,

Волгоградский государственный технический университет

derbisher1@yandex.ru

просп. Ленина, 28, 400131 г. Волгоград, Российская Федерация

\section{Вячеслав Евгеньевич Дербишер}

Доктор химических наук, профессор кафедры технологии высокомолекулярных и волокнистых материалов,

Волгоградский государственный технический университет

derbisher_ve@vstu.ru

просп. Ленина, 28, 400131 г. Волгоград, Российская Федерация

Аннотация. В статье рассматриваются актуальные математические методы (вероятностный, регрессионный, корреляционный, нечеткий, графовый и др.), используемые при исследовании зависимостей «структура - свойство» полимерных композиций и полимерных композиционных материалов. Рассмотрены методология и теоретические аспекты моделирования этих зависимостей, приведены технологические расчеты с использованием моделей. 
Даны примеры анализа частного случая сложных химических и химикотехнологических систем, полимерных композиций и композиционных (полимерных) материалов. Показано возможное решение задач оценки качества композиционных полимерных материалов и рационального выбора состава в однородных наборах с применением нечетких множеств.

Ключевые слова: химико-технологические системы, полимерные композиты, математическое моделирование, идентификация, нечеткие множества, задача оптимизации, выбор ингредиентов. 